IRA-International Journal of Education \& Multidisciplinary Studies ISSN 2455-2526; Vol.07, Issue 02 (2017)

Pg. no. 103-108

Institute of Research Advances

http://research-advances.org/index.php/IJEMS

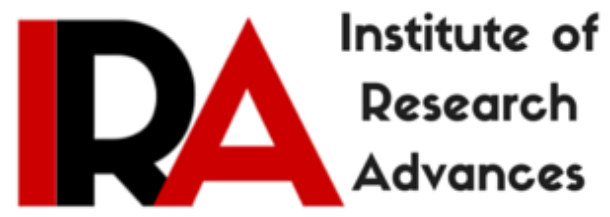

\title{
Problems of North-East People in Metro Cities of India: Need of Human Values for Happy and Healthy Life
}

Dr. N. Aamareswaran

Assistant Professor \& UGC Research Awardee, Dept. of Education, North-Eastern Hill University, Shillong, Meghalaya-793022, India.

Type of Review: Peer Reviewed.

DOI: http://dx.doi.org/10.21013/jems.v7.n2.p7

\section{How to cite this paper:}

Aamareswaran, N. (2017). Problems of North-East People in Metro Cities of India: Need of Human Values for Happy and Healthy Life. IRA International Journal of Education and

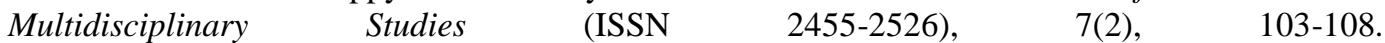
doi:http://dx.doi.org/10.21013/jems.v7.n2.p7

(C) Author.

\section{$(\mathrm{cc})$ BY-NC}

This work is licensed under a Creative Commons Attribution-Non Commercial 4.0 International License subject to proper citation to the publication source of the work.

Disclaimer: The scholarly papers as reviewed and published by the Institute of Research Advances (IRA) are the views and opinions of their respective authors and are not the views or opinions of the IRA. The IRA disclaims of any harm or loss caused due to the published content to any party. 


\begin{abstract}
In the present liberalized, privatized, globalized, scientific, technological, and digit world the life styles of human beings are changing from time to time. A man need values, principles and culture to become human. The main aim of education is all-round development i.e., physical, mental, spiritual, social, political, technological, and economic development of an individual. Education is a key for development. The people from North-East India in general and tribes in particular are migrating to the metro cities of India for better education, health and employment. Because of their physical features and geographical influence people from North-East India are facing problems at metro cities. Sometimes these problems are diverting or converting into a racial discrimination also. The real citizens of India are not treating as citizens of their own country people. It is a painful and not helpful for national integration. Lack of human values in individual is the only single reason behind these problems. In the present paper an attempt has been made to find the different types of problems and causes of problems. It is also suggested the valuable things to do to solve all types of problems for happy and healthy life.
\end{abstract}

Key words: North-East People, Problems, Metro cities, and Human Values.

\title{
Introduction
}

A man need values, principles and culture to become human. In the present liberalized, globalized, privatized, scientific, technological and digital world, the life style of human beings is changing from time to time. Culture is always dynamic. Education and development are two faces of the same coin. Human can strengthen his culture through education. Equity and equality are the foremost values along with peace and non-violence. Values are the guiding principles of life. Equity and equality are possible through education only. In the present complex word people are facing so many types of problems. The people from North-East India are also facing different types of problems in the metro cities of India. There are two types of problems. The first one is nature made problems and the second one is manmade problems. It is difficult and impossible to predict the nature made problems. But, in the case man made problems it is not easy but not impossible.

\section{People from North-East India}

India is a multi-cultural and multi-social country. The North-East India is one of the beautiful and culturally enriched parts of India. North-East India is the eastern-most region of India. Arunachal Pradesh, Assam, Manipur, Meghalaya, Mizoram, Nagaland, Sikkim and Tripura are combinedly as North-East India. The place is also called as states of seven sisters (Arunachal Pradesh, Assam, Manipur, Meghalaya, Mizoram, Nagaland, Tripura) and little brother. There are more than 200 ethnic groups of people are living together. Unity in diversity is the greatness of India in general and NorthEast India in particular.

\section{Metropolitan Cities of India}

The Constitution (Seventy-fourth Amendment) Act, 1992 defines a metropolitan area in India as, an area having a population of one million or more, comprised in one or more districts and consisting of two or more Municipalities or Panchayats or other contiguous areas, specified by the Governor by public notification to be a Metropolitan area. There are 11 metropolitan cities including one metropolitan area in India. They are New Delhi, Mumbai, Kolkata, Bangalore, Pure, Hyderabad, Chennai, Andhra Pradesh Capital Region, Surat, Visakhapatnam, and Kanpur.

\section{Problems of North-East People in Metro Cities of India Migration of People from North-East to Metro Cities}

In the present globalized world people are moving from one country to another country for better education, employment and health facilities. In the same way the people from North-East India are also migrating to metro cities of India for higher education, better employment and good health services and so on. Because of political uncertainty and lack of opportunities regarding better education, employment and health facilities the people in general and educated people in particular are migrating to metro cities of India. 


\section{Types of Problems}

The personality (internal and external) of any individual depends on his/her heredity and environment. The people from North-East India are appears differently when compared to any other parts of India because of geographical impact and heredity. The native people of metro cities including the migrated from different parts of India are not receiving this North-East people nicely.

Many in mainland India feel that racially the Northeasterners are different and represent uncivilized and primitive communities. However, the rise in hate crimes, racial attacks and discrimination has made it difficult for Northeasterners to survive in other parts of India (Aphun, K., 2014). Racial discrimination against North-East people is higher in capital. Over two hundred thousand persons from Northeastern states migrated to Delhi between 2005-2013 and nearly 86 per cent of them have faced sort of "racial discrimination" in metropolitan cities across the county, says the M P Bezbaruah Committee Report, which was set up to look into problems faced by people from North-East in other parts of the country (Mathur, A., 2014). Most of Indian thinks that racism exists only in the West and sees themselves as victims. It's time they examined their own attitudes towards people from the country's North-East (Jilangamba, Y., 2012). 78 out of 100 People from North-East India living in Delhi face racial discrimination (Sangma, M., et. al., 2012).

Based on review of related literature and personal interaction with the people of North-East India at four metro cities of India viz., New Delhi, Kolkata, Bangalore and Mumbai the investigator has identified the following problems which generally face by North-East people. They are:

1) Discrimination

2) Harassment

3) Ill-treatment

4) Racism

5) Racial Attach

6) Abuse

7) Rape and attempt to rape

8) Beating

9) Human Trafficking

10) Molestation

11) Killing

12) Bias at workplace especially for women

13) Getting low salary against to agreement at the time of interview

14) Facing difficulty to get house for rent

15) Calling with unparliamentary words (as chinki, momo, etc.) by native metro people and North-East people too.

\section{Causes of Problems of North-East People}

The main aim of education is all-round development (mental, physical, spiritual, social, political and technological) of an individual. In the present world one more development is added to all-round development i.e. economic development. To say frankly now-a-days education is for earning and employment. Education and Development are two faces of the same coin. There is no development without education. The miserable thing is that now-a-days education is not helping for overall development of an individual. Students are studying hardly to get good marks. They are not practicing the values which they learned at education institutions in their daily life. Values in general and human values in particular are missing in the present day education. People are getting pleasure by insulting others. The fellow human being concept is missing in the life of modern citizens especially in metro cities. People have no time to think about fellow human beings. People make their life themselves busy. The value of human is decreasing because people are giving more value for physical things than human values (Baba, S.S., 2009).

Money makes many things but not all the things. People are running behind money and physical wealth. Unfortunately our educational institutions are also acting as centres of money generating 
instead of generation of future citizens. The employment oriented courses are important but it never becomes the main motto of educational institutions. Life without human values is miserable. Everyone knows the causes of problems. Everyone expects love and honour from others but forget to give same things to others. Don't repeat the things which you feel pain to others. This is a universal solution for all types of problems.

In general individual think that I am normal. But it is not true. The reason behind the social evil like racism is mental disorder. One is four people in the world will be affected mental or neurological disorders at some point in their lives. Around 450 million people currently suffer from such conditions, placing mental disorders among the leading causes of ill-health and disability world word (WHO, 2001). In India, 5 men out of 10 and 7 women out of 10 are need counsellors because they are not normal (NFHS, 2015-16). The above said problems are taking place because of psychological disorders and lack of human values only.

\section{Need of Human Values for Happy and Healthy Life}

Values are the guiding principles, decisive in day to day behaviours as also is critical life situations. Values are a set of principles or standards of behaviour. Values are regarded desirable, important and held in high esteem by a particular society in which a person lives.

Human values are the principles, standards, convictions and beliefs that people adopt as their guidelines in daily activities. Right Conduct, Peace, Truth, Love and Non-violence are the prominent human values. Principal human values are the foundation on which professional ethics are built. They are a set of consistent measures and behaviours that individuals choose to practice in the pursuit of doing what is right or what is expected of them by society. Most laws and legislation are shaped by human values. Human Values are very essential in the present day society.

Be good, see good and do good. That is the way to God. Money comes and goes; but morality comes and grows. Good and bad, peace and agony, pain and pleasure, all these originate within man and not outside him. The past is beyond recovery. We are not sure of the future. The given moment is the right time. Do not delay; do right action (Baba, S.S., 2009). The illiterate of the $21^{\text {st }}$ century will not be those who cannot read and write, but those who cannot learn, unlearn, and relearn (Toffler, A., 1984). There is no age limit to learn new things and valuable things. It is the duty of people those who are facing problem to keep silence when they face problem. Don't upset with people and things. Both are powerless without your reaction. If the occurrence of problem is more then only react to resolve the problem. Education is the most powerful weapon which you can use it to change the world (Mandela, N.). Never search your happiness in others. It will make you feel along. Search it in yourself and you will feel happy even when left alone.

Money and physical wealth never give pleasure but the values can give lifelong pleasure. A person with full of human values can face problems for a moment but overcome it in next moment. Money is not permanent but values are permanent. Money can buy you a bed but not sleep. Money can buy you a clock but not time. Money can buy you a book but not knowledge. Money can buy you a position but not respect. Money can buy you medicine but not health. Money can buy you blood but not life \& money can buy you sex - but not love. This is more useful for each individual for happy and healthy life. Giving is pleasure. It is good to give love to others. Love gives love. The true love never hurt anyone. In the present day we are all facing problems because of lack of human values not because of money and wealth. The human life itself is not permanent but human values are permanent. It is the duty of an individual to give foremost values to human values for happy and healthy life.

\section{Relevance to Need of Society/Country}

The importance of India as a large nation lies in its Unity. Unity is India's strength and Unity in Diversity is the most important feature of India.

In India, national integration alone can be the foundation of a strong, united and prosperous India, especially in these days of extremism and terrorism. Mahatma Gandhi sacrificed his life for 
communal unity. Though, there are Bengalis, Punjabis, Maharastrians, Tamilians, Assamees and Nagas etc., in our country. The fact remains that regardless of divisions and distinctions, caste or creed, we have lived together for thousands of years.

Unfortunately today, instead of unity there seems to prevail, some disunity that hinders national harmony in India. Most of the time the quarrels are between Hindus and Muslims, but sometimes a few other communities have also clashed with each other. Moreover, social and economic inequalities are also responsible for the disunity prevailing in the country. Now we are facing one more problem, which is racism. The majority of North-East people living in metropolitan cities of India are facing racism. The whole North-East India is worrying about it. It is not good for national unity. The NorthEast India has many neighbouring countries. If the situation in this region is not good, it is harmful for whole nation. It is very important and urgent to look into the matter.

\section{Things to Do to Solve the Problems of North-East People}

Education in general and Human Value Education in particular is the most prominent solution to solve all types of problems regarding North-East people in metro cities of India. The following are the most suggestible things to solve the problems of North-East people.

a) Imparting education is one of the best options available to make aware of their rights.

b) More professional and technical higher education must include in their educational careers

c) Need for encouraging women for higher studies within the schools so that school going children may get knowledge of better career from school level which is required for bringing a better education among the women in the Northeast states.

d) More public awareness on prevention and safety against sexual violence, human trafficking and racial discrimination is needed for working women, which could be carried out by the political leaders, community leaders, and student bodies.

e) Basic legal awareness on how to file cases and legal remedies are essential part of sensitization. More cultural integration between people of Northeast region and local communities is needed.

f) The Bezbaruah Committee recommends that when the next the NCERT takes place, one, all teacher training institutes be advised to make their syllabus in a way that can sensitise their trainees on the North East and, two, universities and schools outside the North East make projects on North East a mandatory part of the course curricula.

g) Organization of Seminars, Workshops, and awareness programmes are important to increase the affinity between the metropolitan citizens and North-East people.

Apart from the above list, it is better to concentrate of management skills of personal life and personal relationship. There are five rules of a relationship. They are 1. Stay faithful, 2. Make them feel loved and wanted, 3. Respect your partner, 4. Don't flirt with others, and 5. Make time for each other. Never blame anyone in your life. Good people give you Happiness. Bad people give you Experience. Worst people give you're a lesson. Best people give you Memories. Self-assessment is very important to watch an individual behaviour. It is good to think twice before to do anything/action. This is a success mantra for an individual for happy and healthy life.

\section{Conclusion}

No matter how badly someone treats you, never drop down to their level. Remain calm, stay strong and walk away (lessonslearninginlife.com). We cannot change the past, but we can start a new chapter with a happy ending. If there is righteousness in the heart there will be beauty in character. If there is beauty in character there will be harmony in the home. When there is harmony in the home there will be order in the nation. When there is order in the nation there will be peace in the world (Baba, S.S., 2009). Education in general and Human Values Education in particular is the only one and prominent solution to solve all the types of problems which are faced by North-East people in metro cities of India. Like and love fellow human beings. That gives always pleasure. Nothing is permanent than human values. Protect human values it will protect an individual automatically for happy and healthy life. 


\section{References}

1. Aphun, K. (2014, February 10). North easterners face a lingering sense of fear andinsecurity. Hindustan Times. Retrieved fromhttp://www.hindustantimes.com/analysis/north-easterners-face-a-lingering-senseof-fear-and-insecurity/article 1-1182674.aspx

2. Baba, S.S. (2009). Human Value. Puttaparthi: Sai Publications.

3. Jinlangamba, Y. (2012, June 12). Let's stop pretending there's no racism in India. The Hindu. Retrieved fromhttp://www.thehindu.com/opinion/op-ed/lets-stop-pretendingtheres-no-racism-in-india/article3466554.ece

4. Mathur, A. (2014, August 21). Racial discrimination against NE people higher incapital. Indian

Express. Retrieved fromhttp://indianexpress.com/article/cities/delhi/racial-discrimination-against-nepeople- higher-in-capital/

5. Ministry of Home Affairs (2014). Concerns of the People of the North-East Living in other Parts of the Country. Retrieved from http://mha.nic.in/cc

6. Sangma, M., et.al. (2012, May 1). Mother India \& Her Children from North-East facing Discrimination, Racism? News \&Politics. Podcast retrieved fromhttps://www.youtube.com/watch?v=jWvczZU6yCc

7. Singh, S. (2014, February 24). India needs to learn a lesson about NorthEast. Hindustan

Times. Retrieved from http://www.hindustantimes.com/shivanisingh/india-needs-to-learn-a-lessonabout-northeast/article1-1187484.aspx 